J. Biomater. Sci. Polymer Edn, Vol. 16, No. 6, pp. 699-714 (2005)

(C) VSP 2005.

Also available online - www.vsppub.com

\title{
The effect of radio-frequency glow discharge treatment of polystyrene on the behavior of porcine chondrocytes in vitro
}

\author{
WEI-BOR TSAI ${ }^{1, *}$, TA-CHIN WEI ${ }^{2}$, MEI-CHIAO LIN ${ }^{3}$, JIE-YING WANG $^{2}$ \\ and CHUN-HONG CHEN ${ }^{1}$
}

${ }^{1}$ Department of Chemical Engineering, National Taiwan University, No. 1, Roosevelt Road, Sec. 4, Taipei 106, Taiwan

${ }^{2}$ Department of Chemical Engineering, Chun-Yuan University, Chungli 320, Taiwan

${ }^{3}$ Department of Biomaterials and Tissue Engineering, Biomedical Engineering Center, ITRI, Hsin-chu 300, Taiwan

Received 8 December 2003; revised 23 September 2004; accepted 9 October 2004

\begin{abstract}
The aim of this study was to determine the effects of physicochemical surface properties of tissue-culture substrata on chondrocyte behavior. Polystyrene was modified by radio-frequency glow discharge (RFGD) plasma treatment with various monomers. The changes in surface properties of the modified polystyrene were verified by ESCA and water contact angle measurements. Porcine chondrocytes were seeded on these surfaces and cultured for 5 days. After 5 days of culture, the number of chondrocytes was highest on the $\mathrm{N}_{2}$ plasma-treated surface, followed by the $\mathrm{CH}_{2} / \mathrm{N}_{2}$ plasma-treated surface, untreated polystyrene and $\mathrm{CF}_{4}$ plasma-treated surface. The number of chondrocytes decreased with increasing water contact angle. The surface chemical properties influenced the morphology and gene expression of cultured chondrocytes. The cells cultured on the $\mathrm{CF}_{4}$ plasma-treated surface retained a round morphology characteristic of chondrocytes after day 1 , while most of the cells grown on the $\mathrm{N}_{2}$ plasma-treated surface or the untreated polystyrene showed a flattened morphology. Using RT-PCR, expression of type-I collagen could not be detected in the chondrocytes cultured on the $\mathrm{CF}_{4}$ plasma-treated surface and the $\mathrm{CH}_{2} / \mathrm{N}_{2}$ plasma-treated surface. In contrast, the chondrocytes grown on the $\mathrm{N}_{2}$ plasma-treated surface or the untreated polystyrene surface expressed type-I collagen mRNA. This study shows that modification by RFGD treatment could modulate chondrocyte culture and gene expression.
\end{abstract}

Key words: Chondrocyte; radio-frequency glow discharge; phenotype; surface modification.

*To whom correspondence should be addressed. Tel.: (886-2) 3366-3996. Fax: (886-2) 2362-3040. E-mail: weibortsai@ccms.ntu.edu.twor weiborTsai@ntu.edu.tw 


\section{INTRODUCTION}

Articular cartilage, a tissue lacking nerves, blood system and lymphatic system, covers the articulating end of joints and bears weight loading. Chondrocytes scattered in hyaline cartilage and surrounded by an extra-cellular matrix (ECM) composed of a highly organized macromolecular framework [1]. Chondrocytes regulate the production, organization and degradation of the ECM that is responsible for the mechanical function of the cartilage. It is generally agreed that articular cartilage with relatively low or no turnover is incapable of repairing itself [2], although complete recovery of small full thickness lesions was found in young animals [3]. Therefore, damaged articular cartilage would further degenerate and eventually turn into osteoarthritis [4, 5]. Finally, the damaged knee needs to be replaced by a metal prosthesis.

Tissue engineering, an emergent biomedical field, gives hope to the patients whose articular cartilage is seriously damaged. A successful tissue-engineering product usually contains three important elements, namely cells, scaffolds and biological signals [6]. A therapy based on the concept of tissue engineering has been used to treat patients with damaged articular cartilage clinically for a decade [7]. This cell-based therapy, autologous chondrocyte therapy (ACT), starts with the harvest of a small biopsy from a patient's healthy articular cartilage at an unloaded position. Chondrocytes are isolated from the biopsy and expanded 10-20-fold in vitro. The propagated chondrocytes are then transplanted into the cartilage-defect site of the same patient.

In the cell expansion-stage, monolayer systems, such as dishes and flasks, are routinely used in laboratories. One major pitfall in monolayer culture is that the phenotype of chondrocytes is unstable. The first obvious feature for phenotypic changes is that cell morphology is changed from the characteristically round shape of chondrocytes in native cartilage to a fibroblast-like morphology [8]. Secondly, the ECM proteins secreted from cultured chondrocytes is switched from cartilage-specific type-II collagen, aggrecan and high-molecular-weight proteoglycan to type-I collagen and low-molecular-weight proteoglycan [9-11]. The above phenomena are described as de-differentiation. De-differentiated chondrocytes, when transplanted to cartilage defects, might form a new tissue. However, the newly formed tissue might end up to fibrocartilage, which is mechanically inferior to normal hyaline cartilage and cannot perform long-term weight-bearing duty.

Many studies showed that re-differentiation of de-differentiated chondrocytes happens when the cells are cultured in three-dimensional culture systems, e.g. in agarose or collagen gel [12], in alginate beads [13], or on microcarrier surfaces [14]. Nevertheless, the recovery of chondrocytes phenotype was imcomplete. The 'redifferentiated' chondrocytes still secreted type-I collagen, although they resumed to secrete type-II collagen [15]. Partially re-differentiated chondrocytes might cause discouragingly clinical results.

The maintenance of chondrocyte phenotype during cell expansion should benefit tissue engineering outcome. Culture conditions, like the compositions of culture 
media, temperature and $\mathrm{pH}$, are very important in cell adhesion, growth and function. Besides, a previous study showed that high chondrocyte seeding density could benefit in retaining the chondrocyte phenotype in monolayer culture [16]. Furthermore, the surface properties of culture substrates also influence cell culture. For example, polystyrene, a poorly wetting hydrophobic material with a low surface energy (water contact angle of about $89^{\circ}$ ), does not support cell adhesion well [17-19]. On the other hand, tissue-culture polystyrene (TCPS), commonly used for cell culture in laboratories, is made of polystyrene but modified by radio-frequency glow discharge (RFGD) plasma treatment [20] or exposure to sulfuric acid. Such surface modification greatly enhanced cell adhesion to polystyrene [21]. It was reported that the high densities of surface hydroxyl groups on the oxidation-treated polystyrene enhanced cell adhesion [22].

The purpose of the research reported here was to investigate the influence of surface properties on chondrocyte behavior. RFGD plasma treatment has been a very popular tool in modification of biomaterial surfaces for improving biocompatibility, since this technique merely alters surface physicochemical characteristics without changing underlying bulk properties, For example, RFGD plasma treatment has been applied to modify biodegradable polymers in order to increase cell adhesion to the matrix for tissue engineering applications [4, 23, 24]. Therefore, RFGD plasma with different monomers was used to modify polystyrene surfaces in the current study. The modified polystyrene was characterized by electron spectroscopy for chemical analysis (ESCA) and static water contact angle measurement. The effects of surface modification on chondrocyte culture and gene expression were evaluated.

\section{MATERIALS AND METHODS}

\section{Plasma treatment on TCPS}

Polystyrene Petri dishes (6 $\mathrm{mm}$ in diameter) were purchased from Nunc (Denmark) and used as received. RFGD plasma treatment on polystyrene Petri dishes was carried out in a stainless-steel reactor fitted with a gas inlet, pressure gauge, vacuum system and matching network for capacitive coupling of a $13.56 \mathrm{MHz}$ radio frequency (RF) source. The parallel electrodes housed in the plasma reactor were $20 \mathrm{~cm}$ in diameter and were separated by $2.5 \mathrm{~cm}$. The reactor system was evacuated to $10 \mathrm{~m}$ Torr with a rotary pump. The gases with a flow rate of $5 \mathrm{sccm}$ were then introduced into the reactor through a showerhead. The operating pressure was fixed at 300 mtorr. A RF power of $100 \mathrm{~W}$ was supplied to the upper electrode. Polystyrene Petri dishes placed on the bottom electrode were maintained at $45^{\circ} \mathrm{C}$ during plasma treatment with different monomers: $\mathrm{CF}_{4}, \mathrm{C}_{2} \mathrm{H}_{2} / \mathrm{N}_{2}$ and $\mathrm{N}_{2}$. All plasma-treated samples were rinsed with de-ionized water for post-cleaning.

ESCA spectra for the plasma-treated and untreated samples were recorded on a Physical Electronics ESCA PHI 1600 spectrometer with $\mathrm{Mg} \mathrm{K}_{\alpha}$ excitation at a take-off angle of $54^{\circ}$. The binding energy shift caused by charging up of the film 
due to photoemission was corrected by calibration to the $\underline{\mathrm{C}}-\mathrm{C}$ peak at $285.0 \mathrm{eV}$. The employed deconvolution procedure and the corresponding peak assignments for the ESCA results were in accord with literature recommendations [25-29]. Static water contact angle measurements were performed at $24^{\circ} \mathrm{C}$ using a contact angle meter with a goniometer (FACE CBVP-A3). Using the sessile drop method, every reported contact angle was an average of 10 measurements with a standard deviation below $1^{\circ}$.

\section{Chondrocyte isolation and culture}

Articular cartilage samples were dissected aseptically from pig (9-10 months old) knee joints which were obtained from a local abattoir. The articular cartilage samples were diced into approx. $1 \mathrm{~mm}^{3}$ pieces in autoclaved phosphate-buffered saline (PBS, $137 \mathrm{mM} \mathrm{NaCl}, 2.7 \mathrm{mM} \mathrm{KCl}, 10 \mathrm{mM} \mathrm{Na}_{2} \mathrm{HPO}_{4}$ and $1.8 \mathrm{mM} \mathrm{KH}_{2} \mathrm{PO}_{4}$ ) containing $200 \mu \mathrm{g} / \mathrm{ml}$ gentamicin (Gibco, Cat. No. 1570064) and $25 \mu \mathrm{g} / \mathrm{ml}$ fungizone (Gibco, Cat. No. 1520018). After three rinses with PBS, 1-2 g of the cartilage slivers were digested in $10 \mathrm{ml}$ of DMEM/F12 (Gibco, Cat. No. 12400-024) containing $1 \mathrm{mg} / \mathrm{ml}$ hyaluronidase (Sigma, Cat. No. H-3506) and $1 \mathrm{mg} / \mathrm{ml}$ type-I collagenase (Sigma, Cat. No. C0130) in a $37^{\circ} \mathrm{C} / 5 \% \mathrm{CO}_{2}$ incubator for $18 \mathrm{~h}$. The digestate was filtered through a $70-\mu \mathrm{m}$ filter cell strainer (Falcon, Cat. No. 352350) to remove undigested cartilage lumps. The filtrate was then centrifuged at $200 \times g$ for $10 \mathrm{~min}$ and the cell pellet was resuspended in chondrocyte medium (DMEM/F12 supplemented with $2.5 \mathrm{mM}$ L-glutamine, $200 \mu \mathrm{g} / \mathrm{ml}$ gentamycin, $25 \mu \mathrm{g} / \mathrm{ml}$ fungizone and $10 \%$ bovine calf serum). Cell number and viability were determined with Trypan blue exclusion using a hemocytometer. The freshly-isolated cells were seeded in T75 flask, grown to confluence and then retrieved by trypsin treatment. Chondrocytes at passage 1 were used in this study.

\section{Chondrocyte culture}

Chondrocytes $\left(1 \times 10^{5}\right.$ cells/dish) were seeded on untreated polystyrene dishes or the RFGD-treated ones and then cultured in a humidified $37^{\circ} \mathrm{C} / 5 \% \mathrm{CO}_{2}$ incubator in triplicate. Culture medium was changed every other day. Phase-contrast micrographs of the attached chondrocytes on the untreated polystyrene dishes or the RFGD-treated ones were taken after 1 day incubation. After 5 days, the chondrocytes were harvested after trypsinization and counted using a hemocytometer.

\section{RNA harvest and RT-PCR (Reverse Transcriptase-Polymerase Chain Reaction) analysis}

The expression of $\beta$-actin, type-I collagen and type-II collagen was analyzed by RT-PCR analysis. After the chondrocytes were harvested from the plasmatreated or untreated polystyrene dishes, the total RNA in the cells was extracted by using a single-step method modified from an acid guanidinium-thiocyanatephenol-chloroform extract procedure developed by Chomczyski and Sacchi [30]. 


\section{Table 1.}

Primer sequences for $\beta$-actin, type-I collagen and type-II collagen used in RT-PCR and the predicted length of their PCR products

\begin{tabular}{lll}
\hline Encoded protein & Primer sequences & Length (bp) \\
\hline$\beta$-actin & 5'-AAG GGC TCC GGC ATG TGC-3' $^{\prime}$ & 360 \\
Type-I collagen & $5^{\prime}$-GGG CAG GGG TGT TGA AGG-3' & \\
& $5^{\prime}$-GCT GGC CAA CTA TGC CTC-3' & 318 \\
Type-II collagen & $5^{\prime}$-GAA ACA GAC TGG GCC AAT G-3' & \\
& $5^{\prime}$-TGC CTA CCT GGA CGA AGC-3' & 449 \\
& $5^{\prime}$-CCC AGT TCA GGC TCT TAG-3' & \\
\hline
\end{tabular}

Briefly, the chondrocytes were lysed in $1 \mathrm{ml}$ of $\mathrm{REzol}^{\mathrm{TM}} \mathrm{C} \& \mathrm{~T}$ reagent (PROtech Technology, Taipei, Taiwan) and total RNA was subsequently isolated according to the manufacturer's instructions. Complementary DNA (cDNA) was synthesized from $1 \mu \mathrm{g}$ of total RNA by SUPERSCRIPT ${ }^{\mathrm{TM}}$ II, RNase $\mathrm{H}^{-}$Reverse Transcriptase (Cat. No. 18064-014, Invitrogen) with oligo(dT) priming for $50 \mathrm{~min}$ incubation at $42^{\circ} \mathrm{C}$.

The cDNA was then used as the temperate for PCR amplification. The primer sequences and the length of PCR products for $\beta$-actin, type-I collagen and type-II collagen are listed in Table 1. Amplification was performed in a Gene Amp PCR System 9600 thermocycler for 35 cycles of $95^{\circ} \mathrm{C} / 1 \mathrm{~min}$ denaturation, $55^{\circ} \mathrm{C} / 1 \mathrm{~min}$ annealing and $72^{\circ} \mathrm{C} / 1$ min extension, using recombinant Taq DNA polymerase (Promega, Cat. No. M1861).

The PCR products were analyzed by electrophoresis in a $1 \%$ agarose gel. The resulting bands were visualized after they were stained with ethium bromide and the images were taken under UV-transillumination using Kodak Digital Science DC120 camera. The intensities of bands were analyzed by ONE-DScan for Windows (Spectra Services, Webster, NY, USA). The intensities of the bands for type-I collagen and type-II collagen were normalized to the intensity of the band for $\beta$-actin for the chondrocytes grown on the same surface.

\section{Statistics}

Statistical assessment of significant variations was performed by GraphPad Instat ${ }^{\circledR}$ 3.00 (GraphPad Software). The Welch corrected unpaired $t$-test was conducted to determine $P$-values. All data were reported as mean $\pm \mathrm{SD}$.

\section{RESULTS}

RFGD treatment and surface characterization

The surface chemical compositions and the static water contact angles for the untreated polystyrene and the plasma-treated polystyrene samples are shown in 


\section{Table 2.}

Surface composition and water contact angle of polystyrene and plasma-treated polystyrene samples

\begin{tabular}{lllrrr}
\hline Sample & \multicolumn{3}{l}{ Elemental ratio $(\%)$} & & Contact angle $\left(^{\circ}\right)$ \\
\cline { 2 - 4 } & $\mathrm{C}$ & $\mathrm{N}$ & \multicolumn{1}{c}{$\mathrm{O}$} & \multicolumn{1}{c}{$\mathrm{F}$} & \\
\hline Polystyrene (PS) & 98.5 & 0.0 & 1.5 & 0.0 & 86.5 \\
$\mathrm{CF}_{4}$ plasma-treated PS & 50.6 & 0.0 & 3.0 & 46.4 & 106.7 \\
$\mathrm{C}_{2} \mathrm{H}_{2} / \mathrm{N}_{2}$ plasma-treated PS & 73.3 & 4.2 & 22.5 & 0.0 & 55.5 \\
$\mathrm{~N}_{2}$ plasma-treated PS & 77.7 & 4.7 & 17.6 & 0.0 & 38.6 \\
\hline
\end{tabular}
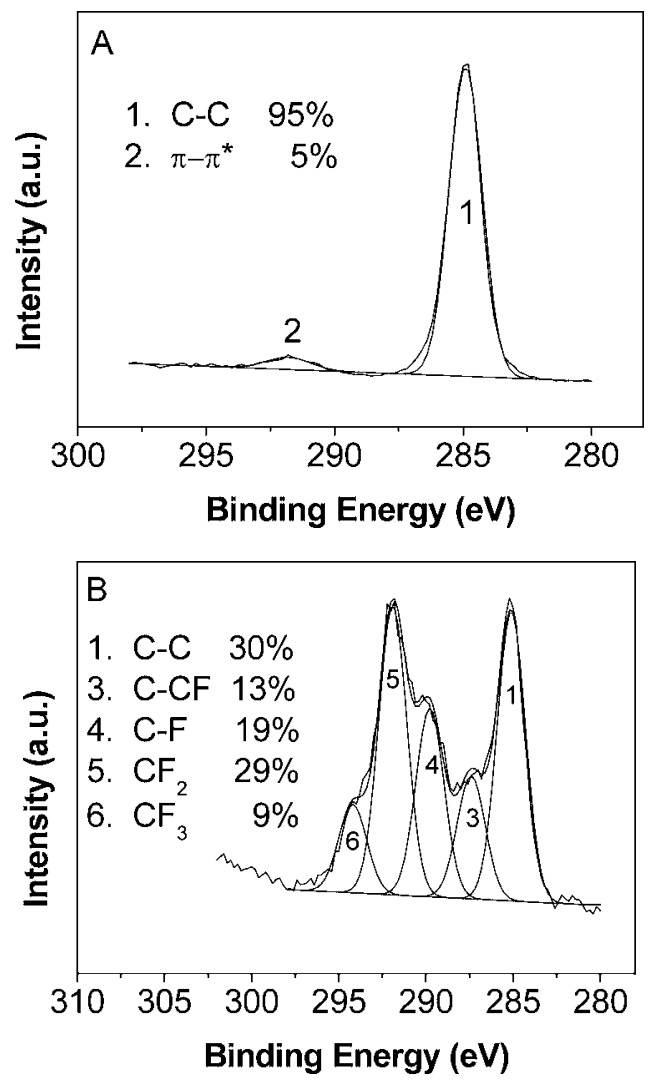

Figure 1. High-resolution ESCA $\mathrm{C}_{1 \mathrm{~s}}$ spectra for RFGD-treated and untreated polystyrene: (A) untreated polystyrene; (B) $\mathrm{CF}_{4}$ plasma-treated polystyrene; (C) $\mathrm{C}_{2} \mathrm{H}_{2} / \mathrm{N}_{2}$ plasma-treated polystyrene; (D) $\mathrm{N}_{2}$ plasma-treated polystyrene.

Table 2. $\mathrm{CF}_{4}$ plasma treatment incorporated a large amount of fluorine atoms onto the polystyrene surface, resulting in a more hydrophobic surface. The static water contact angle for polystyrene was increased from $86^{\circ}$ to $107^{\circ}$ after $\mathrm{CF}_{4}$ plasma treatment. $\mathrm{C}_{2} \mathrm{H}_{2} / \mathrm{N}_{2}$ or $\mathrm{N}_{2}$ plasma treatment introduced nitrogen and oxygen atoms onto the polystyrene surface and, thus, the wettability of the $\mathrm{C}_{2} \mathrm{H}_{2} / \mathrm{N}_{2}$ 

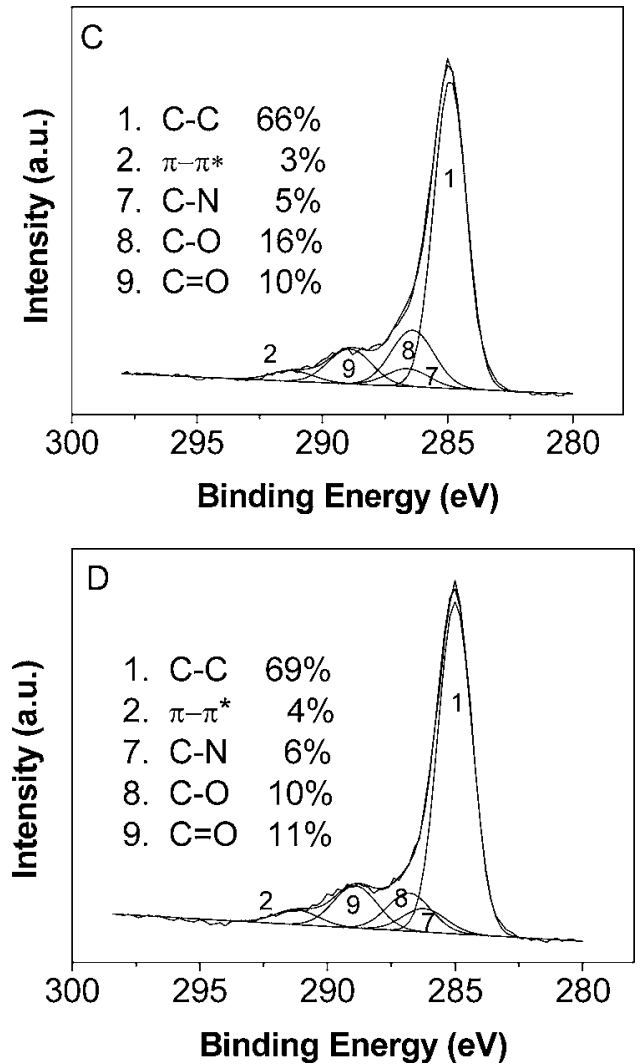

Figure 1. (Continued).

or the $\mathrm{N}_{2}$ plasma-treated polystyrene surfaces improved drastically (Table 2). Although the surface atomic compositions of the $\mathrm{C}_{2} \mathrm{H}_{2} / \mathrm{N}_{2}$ plasma-treated and the $\mathrm{N}_{2}$ plasma-treated surfaces were similar, the $\mathrm{N}_{2}$ plasma-treated surfaces were more hydrophilic than the $\mathrm{C}_{2} \mathrm{H}_{2} / \mathrm{N}_{2}$ plasma-treated ones. It was noted that nitrogen atom incorporation was less than $5 \%$ in the $\mathrm{C}_{2} \mathrm{H}_{2} / \mathrm{N}_{2}$ or $\mathrm{N}_{2}$ plasma-treated samples, but oxygen atom incorporation was more than $17 \%$.

The $\mathrm{C}_{1 \mathrm{~s}}$ ESCA spectra and the relative abundance of various components of the pristine polystyrene and the plasma-treated polystyrene samples are shown in Fig. 1. The spectra of pristine polystyrene (Fig. 1A) showed the characteristic $\underline{C}-\mathrm{C}$ (285.0 eV) and $\pi$-bond shake-up peaks (291.7 eV) [26], reflecting the presence of aromatic rings. The active species in $\mathrm{CF}_{4}$ plasma reacted with polystyrene to form $\underline{\mathrm{C}}-\mathrm{CF}(287.3 \mathrm{eV}), \underline{\mathrm{C}}-\mathrm{F}(289.5 \mathrm{eV}), \underline{\mathrm{C}}-\mathrm{F}_{2}(292.1 \mathrm{eV})$ and $\underline{\mathrm{C}}-\mathrm{F}_{3}(294.0 \mathrm{eV})$ functional groups $[27,28]$, among which the $\mathrm{C}-\mathrm{F}_{2}$ component was the most abundant (Fig. 1B). The $\mathrm{C}_{1 \mathrm{~s}}$ spectra of $\mathrm{C}_{2} \mathrm{H}_{2} / \mathrm{N}_{2}$ and $\mathrm{N}_{2}$ plasma-treated samples were similar (Fig. 1C and 1D). $\underline{\mathrm{C}}-\mathrm{N}(286.1 \mathrm{eV}), \underline{\mathrm{C}}-\mathrm{O}(286.6 \mathrm{eV})$ and $\underline{\mathrm{C}}=\mathrm{O}$ $(288.9 \mathrm{eV})$ functionalities $[25,28,29]$ were produced after plasma treatment. 
However, the $\underline{\mathrm{C}}-\mathrm{O}$ content in $\mathrm{N}_{2}$ plasma-treated samples was less than that in $\mathrm{C}_{2} \mathrm{H}_{2} / \mathrm{N}_{2}$ plasma-treated ones.

\section{Chondrocyte culture}

Isolated porcine chondrocytes were seeded to the plasma-treated or untreated polystyrene surfaces. After 5-day culture the $\mathrm{N}_{2}$ plasma-treated polystyrene exhibited higher cell numbers compared to the untreated polystyrene (Fig. 2, $P<0.05$ for the $\mathrm{N}_{2}$ plasma-treated surface versus the untreated one). In contrast, the number of chondrocytes grown on the $\mathrm{CF}_{4}$ plasma-treated polystyrene was significantly lower than those on the other three surfaces (Fig. 2, $P<0.01$ for the $\mathrm{CF}_{4}$ plasma-treated polystyrene versus all the others). When the cell numbers

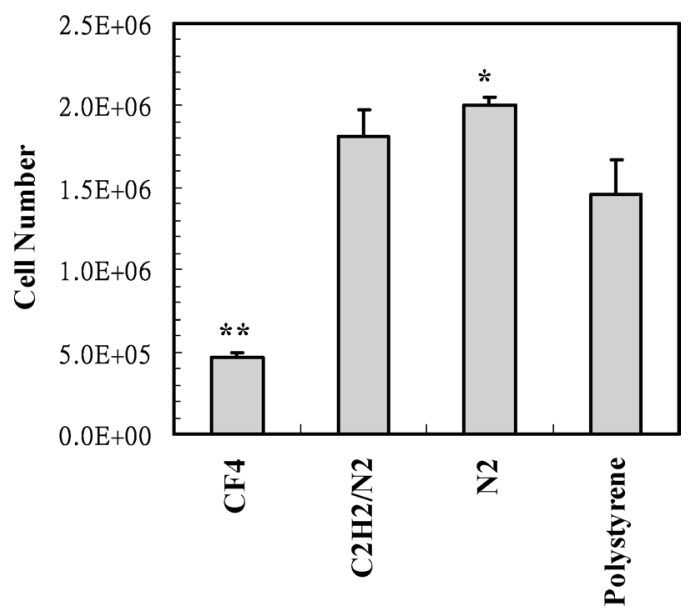

Figure 2. Chondrocyte number after 5 days culture on the plasma-treated and untreated polystyrenes $(n=3$, error bar $=$ standard deviation $) . * P<0.05$ versus polystyrene; $* * P<0.001$ versus other surfaces.

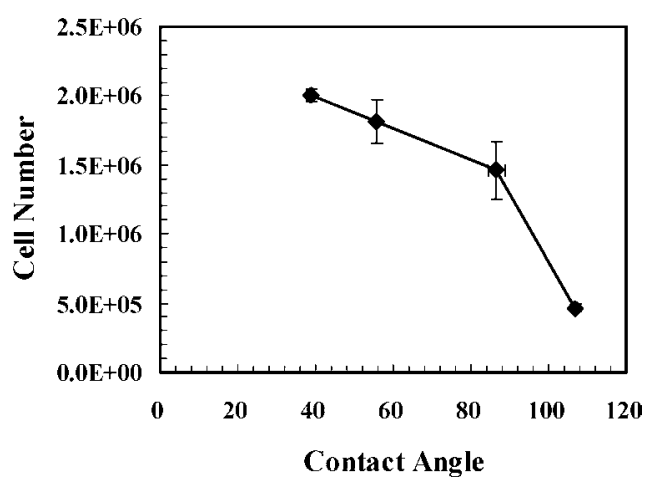

Figure 3. Plot of chondrocyte number after 5 day culture on the plasma-treated and untreated polystyrenes $v s$. the water contact angle of the corresponding surfaces. 
were plotted against the contact angles of the surfaces, it was found that the cell number increased with the surface wettability (Fig. 3).

The cells attached to these surfaces showed differences in morphology after 1 day incubation. The chondrocytes adhered to the $\mathrm{CF}_{4}$ plasma-treated polystyrene still retained a round shape (Fig. 4A), while the majority of the cells attached to the $\mathrm{C}_{2} \mathrm{H}_{2} / \mathrm{N}_{2}$ plasma-treated surface spread (Fig. 4B). Almost all the cells on the $\mathrm{N}_{2}$ plasma-treated polystyrene and the untreated polystyrene showed spread appearance (Fig. 4C and 4D).

\section{RT-PCR analysis of gene expression of type-I collagen, type-II collagen and $\beta$-actin}

RT-PCR analysis has been performed in three independent experiments in which similar results were obtained. Figure 5A represents a typical agarose gel image in which the bands represent the PCR products for $\beta$-actin (as an internal control), type-I collagen and type-II collagen (Fig. 5A). The lengths of the PCR products for $\beta$-actin, type-I collagen and type-II collagen were as predicted. The normalized intensity values in Fig. 5B represent the ratios of the intensity of type-I collagen or type-II collagen bands to the intensity of $\beta$-actin bands for each condition. The normalized intensity for type-I collagen mRNA expression was highest on the $\mathrm{N}_{2}$ plasma-treated surface, followed by that on the untreated surface, whereas the expression of type-I collagen mRNA on the $\mathrm{CF}_{4}$ or $\mathrm{C}_{2} \mathrm{H}_{2} / \mathrm{N}_{2}$ plasma-treated surfaces was undetectable. The normalized intensity for type-II collagen mRNA expression was also highest on the $\mathrm{N}_{2}$ plasma-treated surface and was at a closely low level for the other three surfaces (Fig. 5B).

\section{DISCUSSION}

Four polystyrene-based surfaces different in physiochemical properties were produced by RFGD plasma treatment in this study. $\mathrm{CF}_{4}$ plasma treatment made the polystyrene more hydrophobic than pristine polystyrene, while $\mathrm{C}_{2} \mathrm{H}_{2} / \mathrm{N}_{2}$ and $\mathrm{N}_{2}$ plasma treatment increased polystyrene surface wettability. We noted from the ESCA data that unusually high oxygen contents existed in the surface elemental compositions of the $\mathrm{C}_{2} \mathrm{H}_{2} / \mathrm{N}_{2}$ and the $\mathrm{N}_{2}$ plasma-treated polystyrene. When a sample treated with plasma is exposed to air, surface dangling bonds will react with oxygen or water vapor; therefore, the surface will contain oxygen atoms. Two previous studies regarding polystyrene treated with $\mathrm{N}_{2}$ plasma showed that the oxygen contents were about $60 \%$ higher than the nitrogen contents [31, 32]. However, in this study the oxygen contents in $\mathrm{C}_{2} \mathrm{H}_{2} / \mathrm{N}_{2}$ and $\mathrm{N}_{2}$ plasma-treated samples were 5.4- and 3.7-fold, respectively, higher than the nitrogen contents. We suspected that there must be an oxygen contamination source in the equipment. Thus, we checked the plasma instrument throughout and found out a small leak in the Swageloc fitting for $\mathrm{N}_{2}$ gas. Apparently, the leaking was the reason for the high surface oxygen contents on $\mathrm{C}_{2} \mathrm{H}_{2} / \mathrm{N}_{2}$ and $\mathrm{N}_{2}$ plasma treated samples. Therefore, it may be considered 

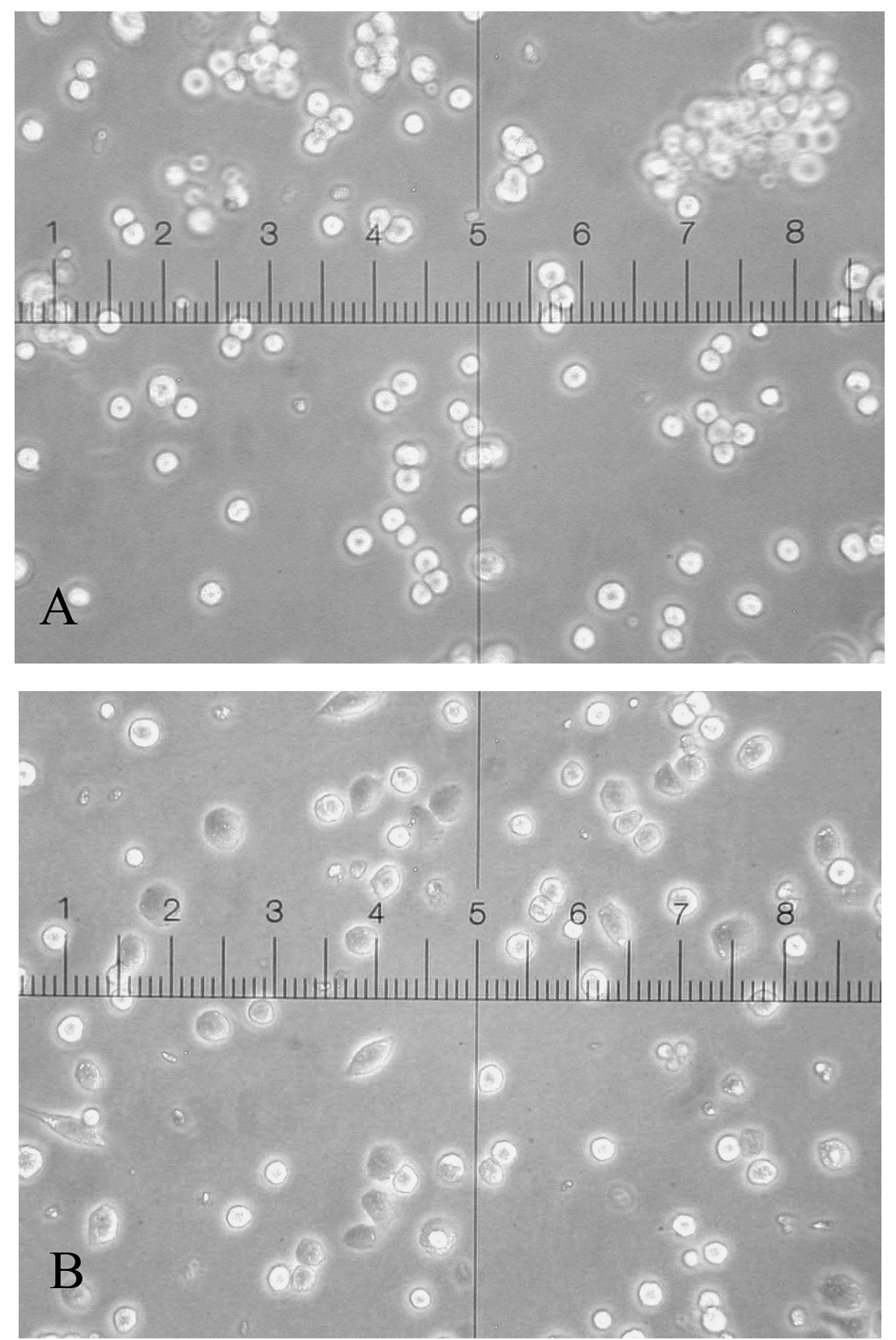

Figure 4. Phase-contrast micrographs of the chondrocytes cultured on the plasma-treated and untreated polystyrene 1 day after cell seeding: (A) $\mathrm{CF}_{4}$ plasma-treated polystyrene; (B) $\mathrm{C}_{2} \mathrm{H}_{2} / \mathrm{N}_{2}$ plasma-treated polystyrene; (C) $\mathrm{N}_{2}$ plasma-treated polystyrene; (D) untreated polystyrene. The major scale in the pictures represents $50 \mu \mathrm{m}$. 

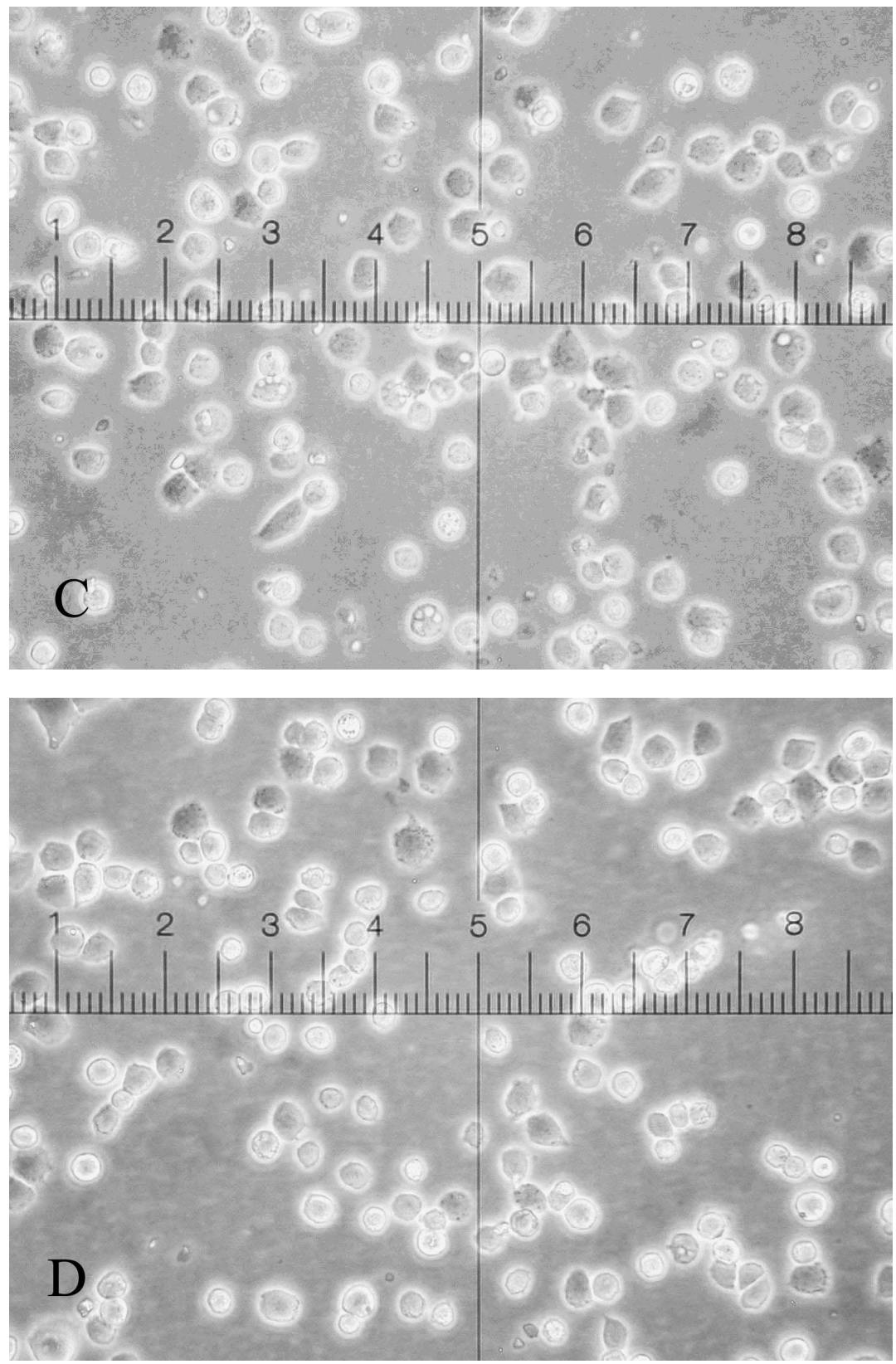

Figure 4. (Continued).

that the $\mathrm{C}_{2} \mathrm{H}_{2} / \mathrm{N}_{2}$ and the $\mathrm{N}_{2}$ plasma-treated polystyrene described in this research were actually modified by a plasma containing air.

Cell adhesion and proliferation on synthetic materials are influenced by the physiochemical properties of the surfaces. For example, surface wettability is 


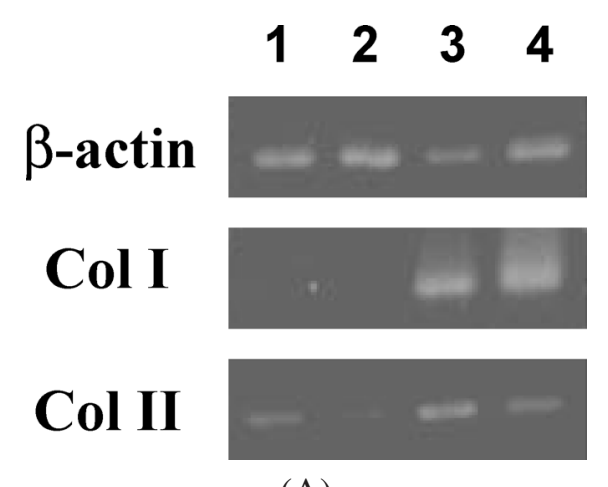

(A)

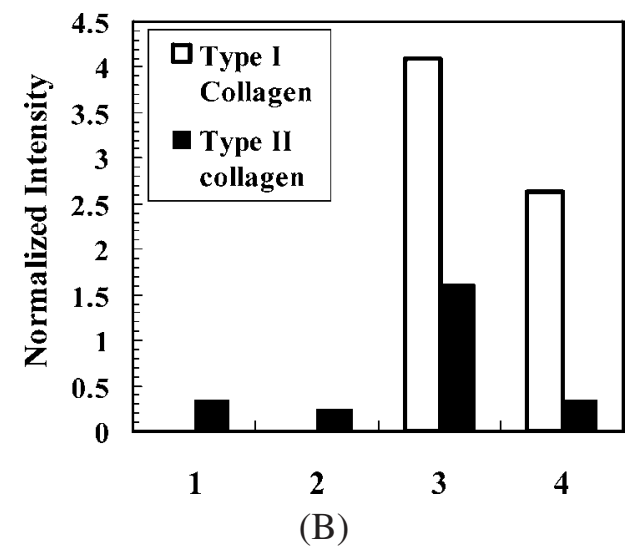

Figure 5. RT-PCR analysis for $\beta$-actin, type-I collagen and type-II collagen. (A) Electrophoresis image of the RT-PCR products; (B) normalized band intensity for type-I collagen and type-II collagen. Lane $1, \mathrm{CF}_{4}$ plasma-treated polystyrene; lane $2, \mathrm{C}_{2} \mathrm{H}_{2} / \mathrm{N}_{2}$ plasma-treated polystyrene; lane $3, \mathrm{~N}_{2}$ plasma-treated polystyrene; lane 4 , untreated polystyrene.

considered to strongly influence cell adhesion and proliferation on a surface [33-37]. A previous study on a series of segmented block co-polymers composed of poly(ethylene glycol terethalate) (PEGT) and poly(butylenes terephthalate) (PBT) showed that the surface with a water contact angle of $37^{\circ}$ was the most favorable for chondrocyte adhesion [38]. In this study, the chondrocyte number was decreased with increasing water contact angles (Fig. 4). The number of chondrocytes after a 5-day culture was highest on the $\mathrm{N}_{2}$ plasma-treated polystyrene whose water contact angle was around $38.6^{\circ}$. These results suggest that a surface with a water contact angle near $38^{\circ}$ is optimal for chondrocyte culture. However, this conclusion should not be expanded to every type of cells. Tamada and Ikada showed that the substrate surface with a water contact angle around $70^{\circ}$ was most favorable for fibroblast adhesion and proliferation [39]. Evans and Steele showed that the attachment and the growth of corneal epithelial cells was better on two hydrophilic surfaces (TCPS and Primaria), but cells also attached effectively to the hydrophobic surface (unmodified polystyrene) [34]. 
The reason why chondrocytes preferred relatively hydrophilic surfaces (water contact angle around $38^{\circ}$ ) is still unclear. Since the culture medium contained serum, it is possible that the surface chemistry influences the adsorption of serum adhesion proteins (e.g., vitronectin and fibronectin), which subsequently modulates cell adhesion. Many studies showed that surface chemistry of synthetic polymers influence cell adhesion through the adsorption of serum fibronectin and/or vitronectin in the culture medium [40-44]. Therefore, chondrocyte culture might be modulated by RFGD treatment of surfaces via the differential adsorption of serum adhesion proteins on substrate surfaces.

In the current study, we investigated the effects of surface modification by RFGD plasma treatment on chondrocyte gene expression. RT-PCR analysis was used in evaluating the gene expression levels of type-I and type-II collagens. RT-PCR is not a quantitative tool for determining gene expression level, but a semi-quantitative analysis was attempted by calculating the ratio of the intensity of type-I collagen or type-II collagen band to that of $\beta$-actin band. Since the RT-PCR experiment has been repeated thrice, these results could represent the relative levels of gene expression for type-I or type-II collagens under each condition.

The chondrocytic phenotype with respect to the expression of type-II collagen mRNA without the expression of type-I collagen mRNA seemed to be retained in the chondrocytes grown on the $\mathrm{CF}_{4}$ or the $\mathrm{C}_{2} \mathrm{H}_{2} / \mathrm{N}_{2}$ plasma-treated surfaces after five days of culturing (Fig. 5B). In contrast, the chondrocytes cultured on the $\mathrm{N}_{2}$ plasma-treated or the untreated polystyrene showed a sign of dedifferentiation (expressing type-I collagen mRNA) although the cells still expressed type-II collagen mRNA (Fig. 5B). Several studies showed that chondrocytes with a round shape is associated with the synthesis of type-II collagen and cartilagespecific proteoglycans $[8,45,46]$. In contrast, flattened fibroblast-like chondrocytes were shown with decreased synthesis of type-II collagen and cartilage-specific proteoglycans and with increased synthesis of type-I collagen [45, 47]. In this study, after 1 day cell culture almost all the chondrocytes grown on the $\mathrm{C}_{2} \mathrm{H}_{2} / \mathrm{N}_{2}$ plasma-treated surfaces (Fig. 4C) and the untreated polystyrene (Fig. 4D) showed a flattened morphology, while most of the chondrocytes cultured on the $\mathrm{CF}_{4}$ plasmatreated surface (Fig. 4A) and some of those cultured on the $\mathrm{C}_{2} \mathrm{H}_{2} / \mathrm{N}_{2}$ plasmatreated surfaces (Fig. 4B) still retained a round shape morphology. Comparing the cell morphology and the type-I collagen expression data, we found a linkage between chondrocyte morphology and phenotype. The results infer that the early induction of type-I collagen gene is accompanied by the early spreading of adherent chondrocytes. The observation suggests that maintenance of chondrocytes' round morphology during culture could retain chondrocytes' phenotype, or at least delay the process of de-differentiation. Although the expression of type-I collagen mRNA was undetectable in the chondrocytes cultured on the $\mathrm{CF}_{4}$ or the $\mathrm{C}_{2} \mathrm{H}_{2} / \mathrm{N}_{2}$ plasmatreated surfaces on day 5 , the possibility that these cells might express type-I collagen for longer culture cannot be excluded. 
Here, we demonstrated that the surface properties of culture substrates influenced chondrocytes behavior. Therefore, an optimal substrate for cell culture could be made by surface modification. An ideal substratum for chondrocyte culture should support a high cell number and maintain chondrocyte phenotype. Among the surfaces studied in the current research, the $\mathrm{CF}_{4}$ plasma-treated surface seems to be able to maintain the chondrocytes' phenotype, but the low cell number after a 5-day culture indicates that this surface is unsuitable for cell expansion. On the other hand, the chondrocytes grown on the $\mathrm{N}_{2}$ plasma-treated or the untreated surface quickly showed signs of de-differentiation (flat morphology and expression of type-I collagen), suggesting that these two surfaces may not be suitable for maintaining chondrocytes' phenotype. Therefore, among the substrates used in this study the $\mathrm{C}_{2} \mathrm{H}_{2} / \mathrm{N}_{2}$ plasma-treated surface seems to be the optimal for chondrocyte culture. However, further investigation is needed to verify if the chondrocytes that are cultured on the $\mathrm{C}_{2} \mathrm{H}_{2} / \mathrm{N}_{2}$ plasma-treated surface have advantages over those proliferating on the other types of surfaces after seeded into a three-dimensional scaffold for tissue engineering.

\section{CONCLUSIONS}

To enhance the efficacy of repairing cartilage defects by tissue engineering approaches, cell expansion with maintenance of cell functions is a critical procedure. This study showed that modification of surface properties of polystyrene by radiofrequency glow discharge treatment could modulate chondrocyte culture and gene expression. This approach, we convincingly attest, can benefit articular cartilage tissue engineering.

\section{Acknowledgements}

The authors sincerely appreciate the financial support from National Science Council, Taiwan (NSC90-2745-P-033-004 and NSC91-2218-E-002-032) and the Ministry of Economic Affairs, Taiwan, ROC.

\section{REFERENCES}

1. A. I. Caplan, Sci. Am. 251, 84 (1984).

2. A. I. Caplan, M. Elyaderani, Y. Mochizuki, S. Wakitani and V. M. Goldberg, Clin. Orthoped. 342, 254 (1997).

3. S. W. O’Driscoll, F. W. Keeley and R. B. Salter, J. Bone Jt. Surg. Am. 68, 1017 (1986).

4. O. A. Gurpinar, K. Tuzlakoglu, M. A. Onur, A. Tumer, M. A. Serdar, N. Unal and E. Piskin, J. Biomater. Sci. Polymer Edn 14, 589 (2003).

5. S. Dore, T. Abribat, N. Rousseau, P. Brazeau, G. Tardif, J. A. DiBattista, J. M. Cloutier, J. P. Pelletier and J. Martel-Pelletier, Arthritis Rheum. 38, 413 (1995).

6. E. Bell (Ed.), in: Principles of Tissue Engineering, p. xxxv. Academic Press, San Diego, CA (2000). 
7. M. Brittberg, A. Lindahl, A. Nilsson, C. Ohlsson, O. Isaksson and L. Peterson, N. Engl. J. Med. 331, 889 (1994).

8. K. von der Mark, V. Gauss, H. von der Mark and P. Muller, Nature 267, 531 (1977).

9. C. W. Archer, J. McDowell, M. T. Bayliss, M. D. Stephens and G. Bentley, J. Cell. Sci. 97, 361 (1990).

10. V. Lefebvre, C. Peeters-Joris and G. Vaes, Biochim. Biophys. Acta 1051, 266 (1990).

11. A. L. Aulthouse, M. Beck, E. Griffey, J. Sanford, K. Arden, M. A. Machado and W. A. Horton, In Vitro Cell Dev. Biol. 25, 659 (1989).

12. T. Kimura, N. Yasui, S. Ohsawa and K. Ono, Clin. Orthoped. 186, 231 (1984).

13. F. Lemare, N. Steimberg, C. Le Griel, S. Demignot and M. Adolphe, J. Cell Physiol. 176, 303 (1998).

14. C. Frondoza, A. Sohrabi and D. Hungerford, Biomaterials 17, 879 (1996).

15. V. Saldanha and D. A. Grande, Biomaterials 21, 2427 (2000).

16. M. Solursh and S. Meier, J. Exp. Zool. 187, 311 (1974).

17. B. D. Ratner, A. B. Johnston and T. J. Lenk, J. Biomed. Mater. Res. 21, 59 (1987).

18. S. I. Ertel, A. Chilkoti, T. A. Horbett and B. D. Ratner, J. Biomater. Sci. Polymer Edn 3, 163 (1991).

19. J. G. Steele, G. Johnson, C. McFarland, B. A. Dalton, T. R. Gengenbach, R. C. Chatelier, P. A. Underwood and H. J. Griesser, J. Biomater. Sci. Polymer Edn 6, 511 (1994).

20. C. F. Amstein and P. A. Hartman, J. Clin. Microbiol. 2, 46 (1975).

21. J. G. Steele, C. McFarland, B. A. Dalton, G. Johnson, M. D. Evans, C. R. Howlett and P. A. Underwood, J. Biomater. Sci. Polymer Edn 5, 245 (1993).

22. A. S. Curtis, J. V. Forrester, C. McInnes and F. Lawrie, J. Cell Biol. 97, 1500 (1983).

23. H. Chim, J. L. Ong, J. T. Schantz, D. W. Hutmacher and C. M. Agrawal, J. Biomed. Mater. Res. 65A, 327 (2003).

24. J. Yang, G. Shi, J. Bei, S. Wang, Y. Cao, Q. Shang, G. Yang and W. Wang, J. Biomed. Mater. Res. 62, 438 (2002).

25. C. Girardeaux, E. Druet, P. Demoncy and M. Delamar, J. Electr. Spectrosc. Relat. Phenom. 70, 11 (1994).

26. C. Girardeaux, E. Druet, P. Demoncy and M. Delamar, J. Electr. Spectrosc. Relat. Phenom. 74, 57 (1995).

27. N. Inagaki, S. Tasaka and Y. Goto, J. Appl. Polym. Sci. 66, 77 (1997).

28. R. Q. Liang, X. B. Su, Q. C. Wu and F. Fang, Surf. Coating. Technol. 131, 294 (2000).

29. C. Jama, O. Dessaux, P. Goudmand, J. M. Soro, D. Rats and J. von Stebut, Surf. Coating. Technol. 119, 59 (1999).

30. P. Chomczynski and N. Sacchi, Anal. Biochem. 162, 156 (1987).

31. R. W. Paynter and H. Benalia, J. Electr. Spectrosc. Relat. Phenom. 136, 209 (2004).

32. J. Grimblot, B. Mutel, V. Moineau, T. Colson, O. Dessaux and P. Goudmand, Surf. Interf. Anal. 30, 415 (2000).

33. T. A. Horbett, J. J. Waldburger, B. D. Ratner and A. S. Hoffman, J. Biomed. Mater. Res. 22, 383 (1988).

34. M. D. Evans and J. G. Steele, J. Biomed. Mater. Res. 40, 621 (1998).

35. T. A. Horbett and M. B. Schway, J. Biomed. Mater. Res. 22, 763 (1988).

36. S. I. Ertel, B. D. Ratner and T. A. Horbett, J. Biomed. Mater. Res. 24, 1637 (1990).

37. J. A. Chinn, T. A. Horbett, B. D. Ratner, M. B. Schway, Y. Haque and S. D. Hauschka, J. Colloid Interf. Sci. 127, 67 (1989).

38. M. Papadaki, T. Mahmood, P. Gupta, M. B. Claase, D. W. Grijpma, J. Riesle, C. A. van Blitterswijk and R. Langer, J. Biomed. Mater. Res. 54, 47 (2001).

39. Y. Tamada and Y. Ikada, J. Biomed. Mater. Res. 28, 783 (1994).

40. P. A. Underwood and F. A. Bennett, J. Cell Sci. 93, 641 (1989).

41. J. G. Steele, G. Johnson, W. D. Norris and P. A. Underwood, Biomaterials 12, 531 (1991). 
42. J. G. Steele, B. A. Dalton, P. A. Underwood and G. J. Smith, J. Cell Sci. 100, 195 (1991). 43. J. G. Steele, G. Johnson and P. A. Underwood, J. Biomed. Mater. Res. 26, 861 (1992).

44. G. Altankov, F. Grinnell and T. Groth, J. Biomed. Mater. Res. 30, 385 (1996).

45. P. D. Benya and J. D. Shaffer, Cell 30, 215 (1982).

46. J. Glowacki, E. Trepman and J. Folkman, Proc. Soc. Exp. Biol. Med. 172, 93 (1983).

47. F. M. Watt and J. Dudhia, Differentiation 38, 140 (1988). 
Copyright of Journal of Biomaterials Science -- Polymer Edition is the property of VSP International Science Publishers and its content may not be copied or emailed to multiple sites or posted to a listserv without the copyright holder's express written permission. However, users may print, download, or email articles for individual use. 